\title{
Pricing Contract Terms in a Crisis: Venezuelan Bonds in 2016
}

\author{
Elena Carletti, Paolo Colla, Mitu Gulati \& Steven Ongena*
}

\section{Introduction}

As of this writing in June 2016, the markets are predicting that Venezuela is on the brink of defaulting on its sovereign debt. On June 1, 2016, the 6 month CDS contract traded at about 7,000 bps which translates into a likelihood of default of over $90 \%$. Our particular interest in the Venezuelan crisis is that its outstanding sovereign bonds have a unique set of contractual features that, in combination with its near-default status, have created a natural experiment. This experiment has the potential to shed light on one of the long standing questions that sits at the intersection of the fields of law and finance.

The question is the degree to which financial markets price contract terms. Under a robust conception of the efficient markets theory, one would expect all relevant public information to get incorporated into the price of a financial security. And that would certainly include information as to the contract terms of a bond that are key to determining the investor's payout when the debtor defaults. But empirical testing of the question of how efficient the sovereign debt markets really are visà-vis contract terms has proved difficult for a variety of reasons, the primary one being that data is rarely available that allows a clean comparison of bonds of the same issuer that are similar in all other characteristics except for a particular contract term (where that contract term has a meaningful likelihood of impacting the investor's payout).

One prominent instance that created a natural experiment that allowed testing of the above proposition was the Greek default in 2012. In that restructuring, Greece paid different types of bonds different payouts as a function of their legal terms; most prominently their governing law and guarantee status. And researchers have found evidence that the markets did anticipate the prediction that the

\footnotetext{
* Carletti and Colla are faculty members at Bocconi University (Finance), Gulati is on the faculty at Duke University (Law) and Ongena is on the faculty of the University of Zurich (Finance). For comments, thanks to Lee Buchheit, Jane Brauer, Anna Gelpern, Mark Stumpf, Mark Weidemaier and an anonymous referee.
} 
foreign law governed Greek bonds and Greek guarantee bonds had a higher potential payout than the generic local law sovereign bonds. ${ }^{1}$

Governing law and guarantee status though are highly salient contract terms. They are features that are obvious to investors from the very front page of the prospectus or offering circular. For example, every investor presumably knows whether he holds a local-law government bond or a foreignlaw one. One just has to look at the length of the sales documents; the former is often no more than a page or two whereas the latter can go into the hundreds of pages of fine print. But what about small differences in the fine print? Are the markets aware of these smaller differences in the legalese and are they able to price securities accordingly?

In the sovereign debt literature, there has been much debate about this question in the context of one contract term in particular: the collective action clause or CAC. The reason for the interest in the pricing of this term, which started roughly in 1995 after the so-called "Tequila crisis" in Mexico, is that the inclusion of this particular type of contract term has been advocated on multiple occasions by a number of policy makers and researchers as a way to improve the international financial architecture. ${ }^{2}$ At the time, the standard contract term governing modifications for foreign sovereign bonds under New York law required unanimous approval of the creditors for any changes to be made to the payment terms of the bond (e.g., principal, interest, maturity, currency). That unanimity requirement, in turn, meant that any attempt at debt restructuring was subject to a significant risk of holdouts. And that risk of the holdouts grabbing a disproportionate share of the pie made all creditors reluctant to enter an exchange. A shift to a lower vote threshold, such as $75 \%$ of the creditors, where a super majority could do a cram-down of dissenting creditors--similar to what most domestic bankruptcy systems allow--was more sensible, the advocates of the CACs argued. Some of them explained that the unanimity provision in New York law bonds was the product of mindless copying from New York law corporate law bond

\footnotetext{
${ }^{1}$ See, e.g., Stephen J. Choi \& Mitu Gulati, The Pricing of Non-Price Terms in Sovereign Bonds: The Case of the Greek Guarantees, 1 J. L. Fin. \& AccT. 1 (2016); Marcus Chamon, Julian Schumacher \& Christoph Trebesch, Foreign Law Bonds: Can They Reduce Sovereign Borrowing Costs, Working Paper, October 2014 draft, available at https://editorialexpress.com/cgi-bin/conference/download.cgi?db_name=RES2015\&paper_id=901

${ }^{2}$ E.g., Barry Eichengreen \& Richard Portes, Crisis, What Crisis: Orderly Workouts for Sovereign Debtors (Center for Economic Policy Research 1995); W. Mark C. Weidemaier \& Mitu Gulati, A People's History of Collective Action Clauses, 54 VA. J. INT'L L. 54 (2013); Anna Gelpern, Ben Heller \& Brad Setser, Count the Limbs: Designing Robust Aggregation Clauses in Sovereign Bonds, in Too LiTtLe, Too LATE: The QUEST TO Resolve Sovereign DeBt CRISES (Martin Guzman, José Antonio Ocampo \& Joseph E. Stiglitz eds., Columbia University Press 2016).
} 
documents. ${ }^{3}$ The counter argument, made by opponents of the CAC reform proposals, was that the unanimity requirement was the product of rational contracting; and was a way for debtors to commit to creditors not to engage in strategic default. ${ }^{4}$

To cut a long story short, the theoretical debate remains as yet unresolved. As a practical matter though, the advocates of CACs won. Starting in April 2003, almost every single New York law governed sovereign bond has moved away from unanimity provisions towards a vote requirement of less than that (usually 75\%). ${ }^{5}$ What interests us here is one of the primary rationales that was given for resolving the debate. And that was that regardless of the merits of the theoretical arguments over whether the unanimity provision was an inefficient historical artifact or a rational attempt to use contracts to constrain moral hazard, markets didn't pay attention to small wording differences in contract terms. ${ }^{6}$ Further, the argument went, if markets weren't going to price the difference between a unanimity requirement for the modification of key terms and a 75\% CAC, then the issuer had every incentive to include the CAC in its bond contracts.

The basis for the foregoing argument was a series of papers that found that bonds with CACs and bonds without CACs did not seem to be priced very differently. ${ }^{7}$ There were questions that could be raised about these initial studies though in that they were usually comparing bonds issued under English law (that tended to have CACs) versus bonds under New York law (that tended to have unanimity provisions). But English and New York law vary in many ways and the contracts written under them also tend to vary in ways well beyond a single provision. Further, the countries who issued in one jurisdiction tended to be different from the ones issuing in the other; adding to the apples versus oranges character of the first generation of CAC pricing studies. Finally, there tend to be a plethora of non-legal factors

\footnotetext{
${ }^{3}$ See Lee C. Buchheit \& Mitu Gulati, Sovereign Bonds and the Collective Will, 51 EMORY L. J. 1317 (2002).

${ }^{4}$ See Michael Dooley, International Financial Architecture and Strategic Default: Can Financial Crises be Made LesS Painful? 53 Carnegie-Rochester Conference Series on Pub. Pol’y, 361 (2000).

${ }^{5}$ See Michael Bradley \& Mitu Gulati, Collective Action Clauses for the Eurozone: An Empirical Analysis, 18 REV. FIN. 2045 (2014).

${ }^{6}$ See Mark Gugiatti \& Anthony Richards, The Use of Collective Action Clauses in New York Law Bonds of Sovereign Issuers, 35 GEO. J. INT'L L. 815 (2003-04).

${ }^{7}$ See Sonke Haseler, Collective Action Clauses in International Sovereign Bond Contracts-Whence the Opposition? 23 J. ECON. SURVEYS 882 (2009).
} 
impacting bond prices--liquidity, geo-political importance of the sovereign, likelihood of a bailout from the IMF, quality of local political institutions and so on. The argument can always be made therefore that the impact of contract terms on price is too difficult to discern using the rough tools available to an econometrician because there are too many factors to control for and not enough data.

The current Venezuelan crisis though has potentially given us a natural experiment to test the foregoing question, albeit in a limited setting. For reasons explained below, Venezuela turns out to have three sets of bonds with different modification provisions-and these are all under New York law and largely identical in all other respects other than their CACs. Further, Venezuela is in deep crisis; as of this writing, its probability of default within the next six months is north of $90 \%$. This is important because this is the scenario where, in theory, legal terms should be most important to market participants. And finally, given the politics of its current government and the general oil glut there is a very low expectation of a bailout from the IMF, any other Official Sector institution. ${ }^{8}$ Put simply, we have a country with multiple bonds under the same law (New York) that have small differences in their contract terms that should matter a great deal to the likely payouts that the holders of these bonds will receive in the event of a default. ${ }^{9}$

We have no doubt that there are some market players who have recognized these differences in contract terms; there have been multiple articles in the financial press noting these differences in legal terms in the Venezuelan sovereign bonds. ${ }^{10}$ The question though is whether this recognition of the variation in contract terms has become widespread enough that it is reflected in the bond prices.

\footnotetext{
${ }^{8}$ The wild card here is China, that has provided considerable financial support to the Venezuelan government over the past decade. Recent reports though suggest that China is seeking to restructure the substantial amounts it has already lent (upwards of $\$ 65$ billion since 2005), rather than lend new money. See Lucy Hornby \& Andres Schipani, China Seeks to Renegotiate Venezuela Loans, FINANCIAL TIMES, June 19, 2016.

${ }^{9}$ Any doubts about whether small differences in contract terms can make an enormous difference in payouts in a sovereign debt restructuring can be resolved by observing what happened in the final resolution of the recent Argentine and Greek debt crises. See, e.g., Jeromin Zettelmeyer, Christoph Trebesch \& Mitu Gulati, The Greek Restructuring of 2012: An Autopsy, 28 Econ. PoL'y 513 (2013); Katia Porzecanski, Singer Makes 369\% of Principal on Argentine Bonds in Debt Offer, BLOOMBERG, March 1, 2016.

${ }^{10}$ E.g., Robin Wigglesworth \& Elaine Moore, Sovereign Debt: Curing Defaults, FINANCIAL TIMES, June 7, 2016; Andres Schipani \& Elaine Moore, Fears of Venezuela Debt Default Rise as Bond Prices Plunge, FINANCIAL TIMES, January 22, 2016; Davide Scigliuzzo, Argentina-Style Legal Drama Looms if Venezuela Defaults on Debt, REUTERS, January 21, 2016.
} 


\section{The Variation in the Venezuelan Bonds}

The reason for there being small differences in the currently outstanding Venezuelan bonds has to do with an unusual set of circumstances surrounding the shift to CACs in the New York market in 2003 and 2004. As noted earlier, there was considerable uncertainty at the time as to how the markets would react to the change in contract terms. In particular, there were those who feared that the markets would react negatively to sovereigns making it easier for them to restructure (that is, investors would charge a higher interest rate to lend to these sovereigns).

Under pressure from the Official Sector institutions such as the IMF and the US Treasury though a number of emerging market sovereigns finally agreed to shift to CACs in early $2003 .{ }^{11}$ But the open question was what the vote threshold for these CACs would be. A drafting committee set up by the G10 group of countries suggested a $75 \%$ vote threshold, but others were advocating higher votes amounts such as $85 \%$. The result was that there was a short period of experimentation and competition where one group of countries, led by Mexico and its lawyers (Cleary Gottlieb), pushed for the 75\% vote threshold to be the market standard and another group and led by Brazil and its lawyers (Arnold \& Porter), tried $85 \%{ }^{12}$ The market did not seem to be imposing an undue penalty on the $75 \%$ bonds as compared to the $85 \%$ ones and by late 2004 the New York law market had coalesced at the $75 \%$ mark. ${ }^{13}$

Important for our purposes though is that Venezuela was in the group led by Brazil. And that means that we have outstanding bonds for Venezuela that have a 100\% vote (the pre 2003 bonds), ones with an $85 \%$ vote (2003 and 2004) and ones with a $75 \%$ vote (post 2004). Other things equal then, the $100 \%$ bonds are going to be easier to hold out on than the $85 \%$ ones which, in turn, are going to be easier to hold out on from than the $75 \%$ ones. The easier it is to hold out, as the recent restructurings of Greece and Argentina have illustrated, the higher one's likely payout will be.

But all other things were not equal, in that the vote threshold was not all that changed in the bonds in $2003-04$. Alongside the shift away from the $100 \%$ vote to the $85 \%$ vote in the Modification

\footnotetext{
${ }^{11}$ For details, see Anna Gelpern \& Mitu Gulati, Public Symbol in Private Contract, 84 WASH. U. L. ReV. 1627 (2007).

${ }^{12}$ See Stephen J. Choi, Eric A. Posner \& Mitu Gulati, The Dynamics of Contract Evolution, 88 N.Y.U. L. Rev. 1 (2013).

${ }^{13}$ Gelpern \& Gulati, supra note 11.
} 
provision, that the external world was focused on, the Venezuelan lawyers also made a tiny change in a different provision of their bonds, the now infamous pari passu clause. ${ }^{14}$ After the enormous recoveries obtained by holdout creditors against Argentina in March 2016, everyone in the sovereign debt world knows this clause. ${ }^{15}$ After all, its specific wording in the Argentine bonds was the basis upon which the New York courts granted the holdout creditors the weapon they needed to bring Argentina to its knees. ${ }^{16}$ But back in 2003, the clause was rather obscure to all but obsessive sovereign debt market watchers. It is easiest to illustrate the change by pointing to the actual language in the contracts, which we reproduce below in relevant part.

The pari passu clause in the pre 2003 (100\% vote) Venezuelan bonds said, in a manner very similar to most other sovereign bonds under New York law at the time:

The payment obligations of [the Republic] under under the [Notes] will at all times rank at least equally with all other payment obligations of Venezuela relating to External Public Debt. ${ }^{17}$

The pari passu clause in the 2003 Venzuelan bond said,

\footnotetext{
${ }^{14}$ We do not know, and have not been able to find out, whether the insertion of these additional words was the product of clever lawyers on the part of Venezuela's counsel or an unthinking change. For those interested in this question, two factors might be relevant. First, the lawyers for Venezuela come from the firm of Arnold \& Porter, one of the two most expert firms doing sovereign side debt work under New York law (the other being Cleary Gottlieb -their top sovereign debt lawyers would have surely known about the implications of the Peru v. Elliott case that came down shortly before the issuance of the Venezuelan 2003 bonds. See Choi et al., supra note 12. Second, the additional language they inserted is not at all standard in New York-law bonds. It is often found in English-law sovereign bonds, but relatively rarely in their New York law counterparts. See W. Mark C. Weidemaier, Robert E. Scott \& Mitu Gulati, Origin Myths, Contracts and the Hunt for Pari Passu, 38 J. L. \& Soc. INQUIRY 72 (2013). As a practical matter though, for a New York court it is the explicit language of the contract rather than speculation about what was in the contract drafter's heads that is likely to control its interpretation.

${ }^{15}$ For discussions of the enormous payouts, see Porzecanski, supra note 9; Matt Levine, Lucrative Toes and Animated Bonds, Bloomberg VieW, March 2, 2016.

${ }^{16}$ The Financial Times dubbed the case "the trial of the century" and has published over 100 articles, blog posts and podcasts about it. See, e.g., Joseph Cotterill, Back to Future with Pari Passu, FT ALPHAVILLE, Nov. 5, 2015, available at http://ftalphaville.ft.com/2013/11/05/1667042/back-to-the-future-with-pari-passu/
}

${ }^{17}$ See Offering Circular, Republic of Venezuela, US \$ 4,000,000,000, 9.25\% Bonds Due 2027 (July 30, 1998$)$, at p. 73. 
The payment obligations of the Republic under the Notes shall, save for such exceptions as may be provided by applicable legislation ... [will] at all times rank at least equally with all its other payment obligations relating to External Public Debt ... ${ }^{18}$

We see above that the November 2003 (85\%) bond has eleven crucial extra words in its pari passu clause, "save for such exceptions as may be provided by applicable legislation" that the equivalent clause in the July 1998 (100\%) bond does not contain. Relevant here, for our purposes, is that these eleven words arguably negate the power of the creditor to use the pari passu clause as a weapon because the "save for such exceptions as may be provided by applicable legislation" modifier that applies to the pari passu clause suggests that the sovereign debtor can, by "applicable legislation" change the pari passu ranking of the bonds whenever it wishes to (so long as it can get the legislature to pass the relevant legislation). ${ }^{19}$

Prior to September 2000, this change would probably have been seen as meaningless. After all, in the pre-2001 period the pari passu clause itself was largely seen by the gurus of the sovereign debt market as a harmless historical artifact. ${ }^{20}$ But in September 2000, a New York hedge fund, Elliott Associates, that had held out from Peru's Brady restructuring some time prior, turned it into a potent weapon. And this bit is crucial because creditors holding out in sovereign debt restructurings prior to this point had had immense difficulty in collecting on their holdout strategy because enforcing against sovereigns in foreign courts was so difficult. The Elliott v. Peru case changed that because Elliott succeeded in persuading an obscure commercial court in Brussels that the pari passu clause entitled it to obtain an injunction against Euroclear (the payment clearing house) paying out Peru's other creditors (the ones who had not held out) unless it, Elliott, was paid a proportional pro rata share. That is, if the creditors holding restructured bonds were paid $100 \%$ of their claims, then Elliott was entitled to be paid

\footnotetext{
${ }^{18}$ See Offering Circular, Bolivarian Republic of Venezuela, US $\$ 1,000,000,000,7 \%$ Notes Due 2018 (Nov. 26, 2003), at p.11.

19 Joseph Cotterill, Ukraine 5\% Notes Due 2015 - And the Burning Tyres Therein, FT - Alphaville (2016), available at http://ftalphaville.ft.com/2014/02/19/1776612/ukraine-1984838000-5-00-per-cent-notes-due-2015-and-theburning-tyres-therein/. We should caution here though that this interpretation of the additional words "save for such exceptions as provided by applicable legislation" has not as yet been tested in court.

${ }^{20}$ Lee C. Buchheit \& Jeremiah Pam, The Pari Passu Clause in Sovereign Debt Instruments, 51 EMORY L. J. 913 (2004).
} 
$100 \%$ of its un-restructured claim. And absent equal proportional payment to each, Elliott claimed (and the court agreed) the pari passu clause was violated. ${ }^{21}$

The Elliott v. Peru case, however, was decided in Brussels (not a major financial or legal center), and that too on an ex parte motion. Lawyers in New York and London, the jurisdictions whose laws under which the vast majority of foreign sovereigns issue debt, were confident that no judge in their jurisdictions would make a determination in this fashion. ${ }^{22}$ And so, the vast majority of pari passu clauses remained unchanged in response to the Peru case in September 2000. Except that is, for a few rare exceptions, such as Venezuela where the lawyers for the issuer appear to have quietly put in a few extra words that potentially defanged the pari passu weapon. ${ }^{23}$ In December 2011, a full decade after the Peru case, the same pari passu dispute showed up before a federal court in New York. And the veteran New York judge, Thomas Griesa, contrary to the predictions of all those lawyers who had heaped contempt on the Brussels court, basically decided in the same way the Brussels court had. Indeed, some might say that he went further. Any institution under his jurisdiction (and given that it was New York, that basically meant every major financial institution in the world) was told that it was at risk of being held in contempt of court if it knowingly assisted Argentina in violating the pari passu clause (as per his interpretation of it). ${ }^{24}$ Argentina, as a result, was basically cut out of the international financial system-and so, in March 2016, it paid; and paid in full (and much more-given interest penalties and lawyers fees). ${ }^{25}$

\footnotetext{
${ }^{21}$ For details, see Buchheit \& Pam, supra note 20.

${ }^{22}$ At least, that was one of the primary explanations many of them gave when interviewed in the years after the Elliott v. Peru case (but before the NML v. Argentina decision on the matter in New York) regarding why they had not changed their clauses in response to the case. See Robert E. Scott \& Mitu Gulati, THE THREE AND A HALF MinUte TRANSACTION: BoIleRPLATE AND THE LIMITS OF CONTRACT DESIGN (University of Chicago Press, 2012).
}

${ }^{23}$ This new language actually starts showing up in Venezuelan bonds as early at 2001, very soon after the Elliott $v$. Peru decision in Brussels in late 2000. The 2001 bonds in question, however, have already matured. See Offering Circular, Bolivaran Republic of Venezuela, Euro 300,000,000, 11\% Notes Due 2008 (March 1. 2001) on p. 9. We should also note that although we earlier attributed the insertion of the new pari passu language in the 2001 bonds to the issuer's lawyers (since it advantaged their client, the issuer), it in theory could have been the two prominent law firms working on the underwriter side on the March 2001 deal (Sullivan \& Cromwell (New York office) and Linklaters (Frankfurt office)).

${ }^{24}$ For details on how this worked, see W. Mark C. Weidemaier \& Anna Gelpern, Injunctions in Sovereign Debt Litigation 31 YALE J. ReG. 189 (2014).

${ }^{25}$ See Robin Wigglesworth, When a Country Defaults, FT-Alphachat (2016), available at http://podcast.ft.com/2016/04/27/when-a-country-defaults/ 
The relevance of the foregoing for our purposes is that the ability of a creditor to effectively utilize a holdout strategy depends not only on its ability to hold out from the restructuring (which is determined by the vote threshold described earlier), but also on its ability to interfere with the sovereign's deal with the other creditors. As a historical matter, interfering with a sovereign's refusal to pay some creditors (typically, the holdouts) while paying the others (the ones who agreed to the restructuring deal) has been near impossible. The sovereign after all has all sorts of sovereign immunities in foreign courts and, even if those have been waived, the sovereign can always hide its assets in its home jurisdiction where foreign courts cannot reach out to it. ${ }^{26}$ The court interpretations of the standard pari passu clause in Brussels in 2001 and New York in 2011 changed all of this because they created a weapon that could bring sovereigns to their knees. Even if foreign courts could not directly force the foreign sovereigns to comply with their orders, they could do so indirectly by imposing costs on those who the foreign sovereigns needed to do business with in their jurisdiction-a very potent threat in a financial center like New York. But this strategy was available only for those creditors who held bonds that had the Argentine or Peruvian style pari passu clauses and whose bonds were governed by the law of a jurisdiction that was a global financial center such as New York.

In the case of Venezuela, that type of clause was present in the Venezuelan bonds issued prior to 2003 (the ones with the 100\% vote requirement issued in 1997 and 1998). Those bonds, therefore, gave holders both the ability to hold out from any restructuring that Venezuela might attempt and a credible threat of being able to use the New York court system to impose high costs on Venezuela if it ever were to do a deal with other creditors without settling with the holdouts. The bonds issued in the post- 2002 period, by contrast had vote thresholds of $85 \%$ and $75 \%$, with the modified or defanged pari passu clause. This meant that these bonds not only would have a lower ability to hold out (as compared to the $100 \%$ one; although the $85 \%$ would do better than the $75 \%$ one), but would also have relatively little power to use the highly potent pari passu weapon against a non-cooperating sovereign debtor. ${ }^{27}$

${ }^{26}$ See, e.g., Ugo Panizza, Jeromin Zettelmeyer \& Frederico Sturzenegger, The Economics and Law of Sovereign Debt and Default, 47 J. ECON. LIT. 1 (2009).

${ }^{27}$ Venezuela's $100 \%$ vote bonds are not completely immune from a restructuring though. There is a restructuring technique called the Exit Amendment that was used to tackle $100 \%$ vote bonds in the pre-CAC era in the New York market. See Lee C. Buchheit \& Mitu Gulati, Exit Consents in Sovereign Bond Exchanges, 48 UCLA L. REV. 59 (2000). 
To summarize, and assuming that we are in a world in which investors are able to price small differences in contract terms, what should we see? The foregoing suggests that the smart money should value the bonds with the $100 \%$ vote requirement and a strong pari passu clause more, and especially so as the crisis worsens, than the $85 \%$ and $75 \%$ ones with the defanged pari passu. More complicated is the question of whether the market will value the $85 \%$ bond more than the $75 \%$ one, given that neither had a strong pari passu clauses. Whether there is a difference will depend on how much the market values the ability to enforce as compared to the ability to holdout. If a holdout strategy is viewed as valuable only if there is an ability to enforce combined with the ability to holdout, then we would expect not to see much of a pricing difference between the two types of bonds. However, if the ability to hold out by itself is viewed as having value, then we should see at least a small difference between the bonds, given that the $85 \%$ one is going to be, other things equal, easier to hold out from.

To provide a preliminary illustration (before we get into the data analysis), we compare in Figure 1 the yields of the $9.25 \%$ September 2027 and the $9.25 \%$ May 2028 bonds. Both bonds have the same coupon rate and maturities are fairly close-less than 8 months apart. Importantly, the former bond is a unanimity bond while the latter has a $75 \%$ vote threshold. As Figure 1 shows, the $100 \%$ bond trades at lower yields throughout -the average yield differential being about -88bps. Figure 2 plots yields for the 7\% December 2018 bond (a 85\% bond) and the 7.75\% October 2019-the 75\% bond with closest coupon and maturity to the former bond. Here bond yields are much closer to each other, especially until the end of 2014, and the average yield differential is $19 \mathrm{bps}$. The overall message of these figures is suggestive that the strong pari passu clause embedded in $100 \%$ bonds is valuable, while market participants treat the $85 \%$ and the $75 \%$ bonds quite similarly.

\section{Data}

Our primary source of information is Bloomberg, from where we select zero and fixed coupon USD denominated bonds issued by Venezuela under New York law and outstanding as of March 1, 2016. We exclude sinkable bonds from our analysis, yielding a sample of 13 bonds. For these bonds we collect from Bloomberg daily mid-yields, prices (mid, ask and bid), amount outstanding between January 4, 2010 (or at the issue date, for bonds issued later than January 4, 2010) and April 29, 2016. We then retrieve from bond prospectuses (sourced from the Perfect Information database) the minimum 
percentage of bondholders required to change the payment terms of an outstanding bond issue. In our sample of Venezuelan bonds, this percentage takes three values: 100\% ( 3 bonds), $85 \%$ ( 2 bonds) and $75 \%$ ( 8 bonds). The cumulative outstanding amount of these bonds is $\$ 23.9$ billion, thus representing about $80 \%$ of Venezuelan sovereign bonds as of this writing in June $2016 .^{28}$

Our empirical analysis builds upon previous work on the effect of CAC provisions on bond yields, using primary or secondary market yields. ${ }^{29}$ The dependent variable is the log of the secondary market mid-yield. To reduce the measurement error that may contaminate daily yields we carry out our analyses at the weekly level and derive weekly (log) yields as simple averages of daily (log) yields in the week.

Our first empirical specification closely mirrors Bradley \& Gulati (2014) who document a linear relation between bond spreads and the minimum vote required to alter the payment terms. Following Bradley and Gulati (2014) we consider as our primary explanatory variable Vote $_{i}$, the minimum percentage of bondholders required to change the payment terms for bond i. For a bond that requires unanimous approval from the creditors for a change, $V_{\text {ote }}$ is coded as 1 . Our empirical strategy is to estimate the following specification:

$$
\mathrm{y}_{\mathrm{i}, \mathrm{t}}=\alpha+\beta \text { Vote }_{\mathrm{i}}+\gamma \mathrm{X}_{\mathrm{i}, \mathrm{t}}+\theta_{\mathrm{i}}+\varepsilon_{\mathrm{i}, \mathrm{t}}
$$

where $\mathrm{y}_{\mathrm{i}, \mathrm{t}}$ is the log of the mid-yield (in \%) for bond i during week $\mathrm{t}, \mathrm{X}_{\mathrm{i}, \mathrm{t}}$ is a vector of control variables, and $\theta_{\mathrm{i}}$ is a bond-specific time invariant effect. Throughout the article we report random-effects (RE) estimation results for our specification(s), and cluster standard errors at the bond level to control for within-bond residual correlation.

The vector $\mathrm{X}_{\mathrm{i}, \mathrm{t}}$ includes variables common to all bonds, as well as bond-specific variables (definitions of the explanatory variables are collected in Table 1). Time variant variables common to all bonds include: the 10YR US benchmark yield (Bm yield ${ }_{t}$, in logs) to account for general movement in

\footnotetext{
${ }^{28}$ The Bank of America Merrill Lynch, Venezuela Viewpoint (12 February 2016) lists, as of January 2016, sixteen Venezuelan sovereign bonds totaling $\$ 32,6$ billion. As a result of our filters, we exclude the $5.75 \%$ February 2016 bond (as it matures before March 1, 2016) and two sinkable bonds (12.75\% August 2022 and 11.95\% August 2031). The total outstanding amount of these sinkable bonds is $\$ 7.2$ billion.

${ }^{29}$ See, e.g., Bradley \& Gulati, supra note 5; Alfredo Bardozetti \& Davide Dottori, Collective Action Clauses: How do they Affect Sovereign Bond Yields? 92 J. INT'L ECON. 286 (2014); Elena Carletti, Paolo Colla, Mitu Gulati \& Steven Ongena, The Price of Law: The Case of Eurozone Collective Action Clauses (2016 draft), available at http://papers.ssrn.com/sol3/papers.cfm?abstract id $=2686879$.
} 
sovereign bond yields, the VIX index as a proxy for market volatility (VIX $\mathrm{t}_{\mathrm{t}}$, in logs), and the spread between US corporate AAA and BBB bonds as a proxy for the credit risk premium (BBB - AAA Spread $\mathrm{d}_{\mathrm{t}}$ in logs). We also construct two variables that measure issuer credit risk. First, we map daily long-term issuer credit ratings issued by Fitch, Moody's and Standard \& Poor's to a numeric scale ranging from 13 (BB-, for Standard \& Poor's) to 18 (CCC, for Fitch and Standard and Poor's, and Caa3 for Moody's). Then we create Rating ${ }_{t}$ as the weekly average of daily averages across the three rating agencies. Higher values of Rating ${ }_{t}$ indicate worse credit ratings. Our second proxy for credit quality is the weekly average of daily 5 YR CDS quotes for Venezuelan senior unsecured debt with the cumulative restructuring clause $\left(\mathrm{CDS}_{t}\right.$, in logs). Figure 3 displays the deterioration of Venezuela credit quality over time: at the beginning of February 2015 all three rating agencies assigned a substantial credit risk (CCC, or worse) and 5YR CDS spreads rose to more than 75\%. During our sample period, the correlation between the variables Rating $\mathrm{t}$ and $\mathrm{CDS}_{\mathrm{t}}$ is more than $90 \%$, which is why in our analyses we include either (rather than both) of these two variables.

Finally, we consider bond-level variables. First, we include residual maturity, given by the difference between a bond maturity and week $\mathrm{t}$ (Resid Mat $\mathrm{i}_{\mathrm{i}, \mathrm{t}}$, in log-weeks). The greater the maturity of a bond, the more likely it is that borrower creditworthiness will change during the life of the bond. Thus, residual maturity proxies for the degree of uncertainty about repayment. Second, we include the coupon rate $\left(\right.$ Coupon $_{i}$, in percentage) since there is sometimes a tax related preference for higher coupon bonds. Third, we use the bid-ask spread (BA Spread ${ }_{i, t}$, in percentage) as a proxy for bond liquidity. ${ }^{30}$ Descriptive statistics for our control variables are provided in Table 2.

Regression results for specification (1) are reported in Table 3. The US-based macro variables are significant and with the expected sign: Venezuelan bond yields are positively affected by the general level of sovereign yields, the market volatility and the credit risk premium. Yields are also inversely related to the issuer creditworthiness. According to Table 3, a one notch deterioration in average credit

\footnotetext{
${ }^{30}$ The majority of existing studies employ primary market data and thus measure bond-level liquidity with the issue size. Similarly, we could use a bond's outstanding amount here. However, this variable turns out to be timeinvariant (at the individual bond level) in our sample of bonds. We therefore choose to resort to the bid-ask spread which shows both cross-sectional and time-series variation and thus we believe can provide more timely signals of bond-specific liquidity.
} 
ratings increase yields by $22.5 \%(=1-\exp (-0.255)) .{ }^{31}$ Since, according to Table 2, bond yields are, on average, $15.44 \%$ (=exp(2.737)), our coefficient on Rating translates a one-notch deterioration into a $347 \mathrm{bps}$ increase in yields. Table 3 further shows that a $10 \%$ increase in sovereign CDS spreads leads to a 70bps decrease in yields.

Turning to bond-level variables, we uncover a negative association between residual maturity and yields. Although this may at first be surprising, it is consistent with the idea that for issuers with poor credit quality, the passage of time can offer an improvement in their creditworthiness (in colloquial terms, the yield curve flips). ${ }^{32}$ Coupon rate and the bid-ask spread do not appear to affect bond yields. Moreover, yields are not affected by our variable of interest, Vote. ${ }^{33}$

An explanation behind the lack of significance of Vote is that the relation between the minimum percentage of bondholders required to change the payment terms and (log-)yields is non-linear. Put differently, remember that the bonds with a $100 \%$ vote contained a potent pari passu clause, whereas the bonds with the $75 \%$ and $85 \%$ voted contained a defanged one. That should, if investors were paying attention to the legalese, mean a significantly different pricing relationship between the $100 \%$ and $85 \%$ bonds and the $85 \%$ and $75 \%$ bonds.

\footnotetext{
${ }^{31}$ This result is consistent with Cantor \& Packer (1996) that, using secondary market spreads on 35 sovereign bonds, estimate the effect of a one-notch downgrade to be a $25 \%$ increase in spreads. Similarly, Kamin \& von Kleist (1999), using primary market spreads on about 300 sovereign bonds, estimate an increase by $26 \%$ following a onenotch downgrade in the speculative grade range. See Richard Cantor \& Frank Packer, Determinants and Impact of Sovereign Credit Ratings, FRB(NY) ECON. PoL'Y REV. (October) 37 (1996); Steven B. Kamin \& Karsten von Kleist, The Evolution and Determinants of Emerging Market Credit Spreads in the 1990s, BIS Working Paper 68 (1999).

${ }^{32}$ See, for example, the discussion in Stephen J. Choi, Eric A. Posner \& Mitu Gulati, Pricing Terms in Sovereign Debt Contracts: A Greek Case Study, 6 CAP. MKTS. L. J. 163 (2011). Along these lines, Fons (1994) documents that spreads on lower-rated US corporate issuers narrow with maturity, while those of higher-rated firms widen. Similarly, Kamin \& von Kleist (1999) report a diminished responsiveness of sovereign spreads to maturity as credit ratings deteriorate. See Jerome S. Fons, Using Default Rates to Model the Term Structure of Credit Risk, 50 Fin. ANAL. J. 25 (1994); Kamin \& von Kleist, supra note 32.

${ }^{33}$ At a first glance this result is inconsistent with Bradley \& Gulati (2014) (supra note 5) that reports a statistically significant 2 bps increase in spreads on bonds written under New York law due to a $1 \%$ increase in the minimum percentage of bondholders required to change the payment terms (see Table IX in Bradley \& Gulati 2014). We note however that the estimated coefficient on Vote is not statistically different from zero in Bradley \& Gulati (2014) as well for non-investment grade issuers once the authors control for the state of the world economy (see Table $\mathrm{X}$ ). Therefore, as Venezuela is a non-investment grade issuer during our sample period, our findings are indeed consistent with those in Bradley \& Gulati (2014) to the extent that our variables Bm yield, VIX and BBB AAA Spread track the state of the world economy reasonably well.
} 
To investigate the foregoing, we estimate the following specification:

$$
\mathrm{y}_{\mathrm{i}, \mathrm{t}}=\alpha+\beta_{1} \text { Vote } 85_{\mathrm{i}}+\beta_{2} \text { Vote } 100_{\mathrm{i}}+\gamma \mathrm{X}_{\mathrm{i}, \mathrm{t}}+\theta_{\mathrm{i}}+\varepsilon_{\mathrm{i}, \mathrm{t}}
$$

where Vote $85_{\mathrm{i}}$ (resp. Vote $100_{\mathrm{i}}$ ) equals one for a bond with Vote $_{\mathrm{i}}=0.85\left(\right.$ resp. Vote $_{\mathrm{i}}=1$ ) and zero otherwise. Note that, by means of Vote $85_{i}$ and Vote $100_{i}$ we are now coding the minimum vote threshold differently from what we previously did with the variable Vote $\mathrm{i}_{\mathrm{i}}$. This bears on the interpretation of the $\beta$ s across our regressions: while $\beta$ in specification (1) corresponds to the change in (log-)yields associated with a $1 \%$ change in the minimum vote threshold, $\beta_{1}$ and $\beta_{2}$ in specification (2) encapsulate the differential yield on a $85 \%$ and a unanimity bond, respectively, relative to a bond with a 75\% vote requirement (baseline). Columns 3 and 4 in Table 3 report regression results for this specification, and show that, while $\beta_{1}$ is insignificant, $\beta_{2}$ is negative and significant. It therefore appears that, while markets do not price differently a $75 \%$ and a $85 \%$ bond, they do differentiate between the unanimity bond (with the strong pari passu) and the two bonds with the lower vote requirement (and weaker pari passu clauses).

Our estimates indicate that yields on a unanimity bond are $8.7 \%$ to $10.86 \%$ lower than yields on a $75 \%$ bond. Since the average yield on $75 \%$ bonds in our sample is $15.25 \%$, the unanimity rule is associated with a $133 \mathrm{bps}$ to $166 \mathrm{bps}$ yield reduction. To put these numbers into perspective, the interquartile range of yields on $75 \%$ bonds is $527 \mathrm{bps}$ so that the average yield reduction we document for unanimity bonds corresponds to $25 \%-30 \%$ of the distribution of $75 \%$ bonds. One can read this evidence as suggesting two possibilities.

First, putting aside the pari passu clause, the foregoing might be saying that there is a substantial pricing premium for bonds that face a higher risk of holdout problems, but only for those bonds where this risk is highest. It is possible that the market puts a huge value on the unanimity vote requirement where there is a zero possibility of a cram down by a super majority of creditors. That is a possibility, but it is somewhat puzzling why the market would not attach at least some pricing premium to a $10 \%$ difference in a vote threshold (between $85 \%$ and $75 \%$ ) when it seems to attach an enormous difference to a $15 \%$ premium (between $100 \%$ and $85 \%$ ). That then takes us to the second, and we think more plausible, possibility, which is that the market is not only concerned about differences in the vote thresholds but also the strength of the pari passu clause. To take this back to the question that we began the article with: We are finding evidence that the market, in a near-default situation, is able to 
parse small differences in the legalese. ${ }^{34}$ At least, more so than prior research has discerned. The caveat is that we only have a handful of bonds, and only bonds for one sovereign.

\section{Conclusion}

Our finding is that in a near-default scenario the markets do seem to be able to discern the difference between bonds that allow for a greater ability to hold out and the others. Prior research, in particular in the context of the Greek restructuring of 2012 had found evidence consistent with what we report here. But that research was looking at highly salient contract features, such as whether the bonds were governed by local (Greek) law or foreign (English) law. Here, we drill deeper and look at whether the markets can discern smaller (albeit potentially significant) differences in the fine print legalese in the bonds. And we find, in the case of Venezuelan sovereign bonds in 2016, evidence consistent with the premise that markets are able to discern these differences.

There remains a puzzle though, which is that our finding contrasts with the existing literature on CAC provisions that has largely found either no pricing difference or a pricing premium for bonds with lower vote thresholds (the latter being the the opposite of what we find). ${ }^{35}$ The explanation for this difference in findings may be that most of research on the pricing of CAC provisions looks at countries that are doing reasonably well economically. The investors in those cases are primarily, we suspect, large institutions or unsophisticated retail investors - their reason for investing in government bonds is that they are generally safe investments. In a near-default scenario though, those types of investors tend to exit and are replaced by the wolves of the market-sophisticated hedge funds, many of whom have lawyers who carefully parse contracts seeking an advantage for their investors. ${ }^{36}$ As noted above,

\footnotetext{
${ }^{34}$ One potential concern with our interpretation relates to the relative size of bonds with different voting thresholds. For instance, if unanimity bonds represented a large fraction of the debt stock, it might be unlikely that they get repaid in full regardless of their voting thresholds. The three $100 \%$ bonds in our sample total \$5 billion, which is about $16 \%$ of the Venezuelan debt stock as of June 2016 --probably not too large a fraction. Similarly, it might be easier to hold out in a $75 \%$ bond that is small than in an $85 \%$ bond that is large. However, bond size is fairly similar across these two groups of bonds: $75 \%$ bonds range between $\$ 1.25$ billion and $\$ 3$ billion, while the two $85 \%$ bonds have size $\$ 1$ billion and $\$ 1.5$ billion, respectively.

${ }^{35}$ E.g., Haseler, supra note 7 (reviewing the literature); see also Carletti et al., supra note 30; Bradley \& Gulati, supra note 5. An exception here is Barry Eichengreen \& Ashoka Mody, Do Collective Action Clauses Raise Borrowing Costs? 114 Econ. J. 247 (2004).

${ }^{36}$ These funds are often described as engaging in "legal arbitrage" or "contract arbitrage" strategies. See Stephen J. Choi, Robert E. Scott \& Mitu Gulati, Contractual Arbitrage, Oxford Handbook of Global Governance (Eric Brousseau et al. eds., forthcoming 2017).
} 
when we compare our results to the research that focuses on bonds in near-default scenarios, they are largely consistent with them. ${ }^{37}$ What we document is also consistent with the idea that market participants (or at least some of them) have learned from the lengthy legal fight between Argentina and holdout investors that the absence of collective action clauses can be exploited to block a sovereign restructuring and obtain full repayment.

${ }^{37}$ E.g., Choi et al., supra note 12; Choi \& Gulati, supra note 1; Chamon et al., supra note 1; Andrew Clare \& Nicolas Schmidlin, The Impact of Foreign Governing Law on European Government Bond Yields (2014 draft), available at http://papers.ssrn.com/sol3/papers.cfm?abstract_id=2406477 
Table 1. Definition of variables. This table provides a detailed description of our variables. All variables are weekly averages of daily values, with the exception of Coupon and Vote that are time-invariant bond-level variables.

\begin{tabular}{|c|c|c|c|}
\hline Variable & Description & Units/Scale & Source \\
\hline Vote & $\begin{array}{l}\text { Minimum percentage of bondholders required to change the payment } \\
\text { terms. } 100 \% \text { is coded as Vote }=1\end{array}$ & Decimals & Perfect Info \\
\hline Vote 85 & $=1$ if Vote $=0.85,=0$ otherwise & Binary & Perfect Info \\
\hline Vote 100 & $=1$ if Vote $=1,=0$ otherwise & Binary & Perfect Info \\
\hline Bm yield & US government benchmark yield 10YR & $\%(\log )$ & Datastream \\
\hline VIX & VIX Index, settlement price & $\%(\log )$ & Datastream \\
\hline BBB-AAA Spread & Yield spread between BofA Merrill Lynch US corporate AAA and BBB & bps (log) & Datastream \\
\hline Rating & $\begin{array}{l}\text { Average of foreign currency LT debt issuer rating given by Fitch, Moody's } \\
\text { and S\&P }\end{array}$ & $13(\mathrm{BB}-)$ to $18(\mathrm{CCC})$ & Bloomberg \\
\hline CDS & 5YR CDS spread, senior unsecured debt with CR clause & $\%(\log )$ & Markit \\
\hline Resid Mat & Distance to maturity & Months (log) & Bloomberg \\
\hline Coupon & Annual coupon & $\%$ & Bloomberg \\
\hline BA Spread & Percentage bid-ask spread $\left(\mathrm{P}_{\mathrm{ASK}}-\mathrm{P}_{\mathrm{BID}}\right) / \mathrm{P}_{\mathrm{MID}}$ & $\%$ & Bloomberg \\
\hline
\end{tabular}


Table 2. Descriptive statistics. This table presents means, medians, $5^{\text {th }}$ and $95^{\text {th }}$ percentiles for our sample of Venezuelan bonds. The sample period ranges between 4 January 2010 and 29 April 2016. Variables in Panel A are time-variant bond-invariant. Variables in Panel B are time- and bond-variant with the exception of Vote and Coupon, which are time-invariant.

\begin{tabular}{lccccc}
\hline \multicolumn{7}{c}{ Panel A: bond-invariant variables } \\
\hline Variable (unit) & Mean & Median & $5^{\text {th }}$ Perc. & $95^{\text {th }}$ Perc. & N. Obs. \\
\hline Bm yield (\%, log) & 0.858 & 0.831 & 0.496 & 1.288 & 330 \\
VIX (\%, log) & 3.016 & 2.978 & 2.730 & 3.449 & 330 \\
BBB-AAA Spread (bps, log) & 5.000 & 5.056 & 4.576 & 5.397 & 330 \\
Rating (index) & 15.321 & 14.333 & $14(\mathrm{~B}+)$ & $18(\mathrm{CCC})$ & 330 \\
CDS (\%, log) & 2.680 & 2.347 & 1.942 & 4.157 & 330 \\
\hline \multicolumn{5}{l}{ Panel B: bond-level variables } \\
\hline Variable (unit) & Mean & Median & $5^{\text {th }}$ Perc. & $95^{\text {th }}$ Perc. & N. Obs. \\
\hline Yield (\%, log) & 2.737 & 2.624 & 2.247 & 3.579 & 4,188 \\
Vote & 0.823 & 0.75 & 0.75 & 1 & 13 \\
Resid Mat (months, log) & 4.821 & 4.889 & 3.799 & 5.687 & 4,188 \\
Coupon (\%) & 9.194 & 9.0 & 6.0 & 13.625 & 13 \\
BA Spread (\%) & 1.177 & 0.840 & 0.000 & 4.221 & 4,188 \\
\hline
\end{tabular}


Table 3. Minimum vote thresholds and yield differentials. This table presents random (bond-level) effects regression results to examine the relation between the minimum percentage of bondholders required to change the payment terms CAC provisions and bond yields. The sample ranges from January 4, 2010 to April 29, 2016 and includes 13 Venezuelan bonds. The dependent variable is weekly log-yield. Definitions of the explanatory variables are provided in Table 1. Standard errors are clustered at the bond level. $* *, * *$, and $*$ denote statistical significance at the $1 \%, 5 \%$, and $10 \%$ level, respectively.

\begin{tabular}{|c|c|c|c|c|}
\hline & (1) & (2) & (3) & (4) \\
\hline Vote & $\begin{array}{l}-0.685 \\
(0.529)\end{array}$ & $\begin{array}{l}-0.778 \\
(0.602)\end{array}$ & & \\
\hline Vote 85 & & & $\begin{array}{c}0.011 \\
(0.024)\end{array}$ & $\begin{array}{c}0.006 \\
(0.044)\end{array}$ \\
\hline Vote 100 & & & $\begin{array}{c}-0.091 * * \\
(0.046)\end{array}$ & $\begin{array}{c}-0.115^{*} \\
(0.069)\end{array}$ \\
\hline Bm yield & $\begin{array}{c}0.468 * * * \\
(0.027)\end{array}$ & $\begin{array}{c}0.241^{* * *} \\
(0.019)\end{array}$ & $\begin{array}{c}0.425^{* * *} \\
(0.021)\end{array}$ & $\begin{array}{c}0.172^{* * *} \\
(0.011)\end{array}$ \\
\hline VIX & $\begin{array}{c}0.481 * * * \\
(0.027)\end{array}$ & $\begin{array}{c}0.214^{* * *} \\
(0.029)\end{array}$ & $\begin{array}{c}0.433 * * * \\
(0.022)\end{array}$ & $\begin{array}{c}0.146 * * * \\
(0.023)\end{array}$ \\
\hline BBB-AAA Spread & $\begin{array}{c}0.389 * * * \\
(0.039)\end{array}$ & $\begin{array}{c}0.174^{* * *} \\
(0.031)\end{array}$ & $\begin{array}{c}0.378^{* * *} \\
(0.039)\end{array}$ & $\begin{array}{c}0.135^{* * *} \\
(0.030)\end{array}$ \\
\hline Rating & $\begin{array}{c}0.256 * * * \\
(0.012)\end{array}$ & & $\begin{array}{c}0.279 * * * \\
(0.016)\end{array}$ & \\
\hline CDS & & $\begin{array}{c}0.452 * * * \\
(0.022)\end{array}$ & & $\begin{array}{c}0.491 * * * \\
(0.026)\end{array}$ \\
\hline Resid Mat & $\begin{array}{c}-0.378 * * * \\
(0.044)\end{array}$ & $\begin{array}{c}-0.422^{* * *} \\
(0.055)\end{array}$ & $\begin{array}{c}-0.146 * * * \\
(0.016)\end{array}$ & $\begin{array}{c}-0.186 * * * \\
(0.019)\end{array}$ \\
\hline Coupon & $\begin{array}{c}0.009 \\
(0.020)\end{array}$ & $\begin{array}{c}0.009 \\
(0.024)\end{array}$ & $\begin{array}{c}0.016^{* *} \\
(0.006)\end{array}$ & $\begin{array}{l}0.016^{*} \\
(0.009)\end{array}$ \\
\hline Bid-Ask Spread & $\begin{array}{c}0.008 \\
(0.007)\end{array}$ & $\begin{array}{l}0.008^{*} \\
(0.004)\end{array}$ & $\begin{array}{c}0.010 \\
(0.010)\end{array}$ & $\begin{array}{c}0.010 \\
(0.006)\end{array}$ \\
\hline Obs & 4,188 & 4,188 & 4,188 & 4,188 \\
\hline R-overall & 0.818 & 0.848 & 0.892 & 0.944 \\
\hline
\end{tabular}


Figure $1.100 \%$ vs $75 \%$ vote threshold. Weekly time series of average yields for the $9.25 \%$ September 2027 (ISIN US922646AS37) and the 9.25\% May 2028 (ISIN USP17625AB33) bonds (top panel) and yield differential between the two bonds (bottom panel). The dashed line in the bottom panel indicates the average yield differential (-88 bps).

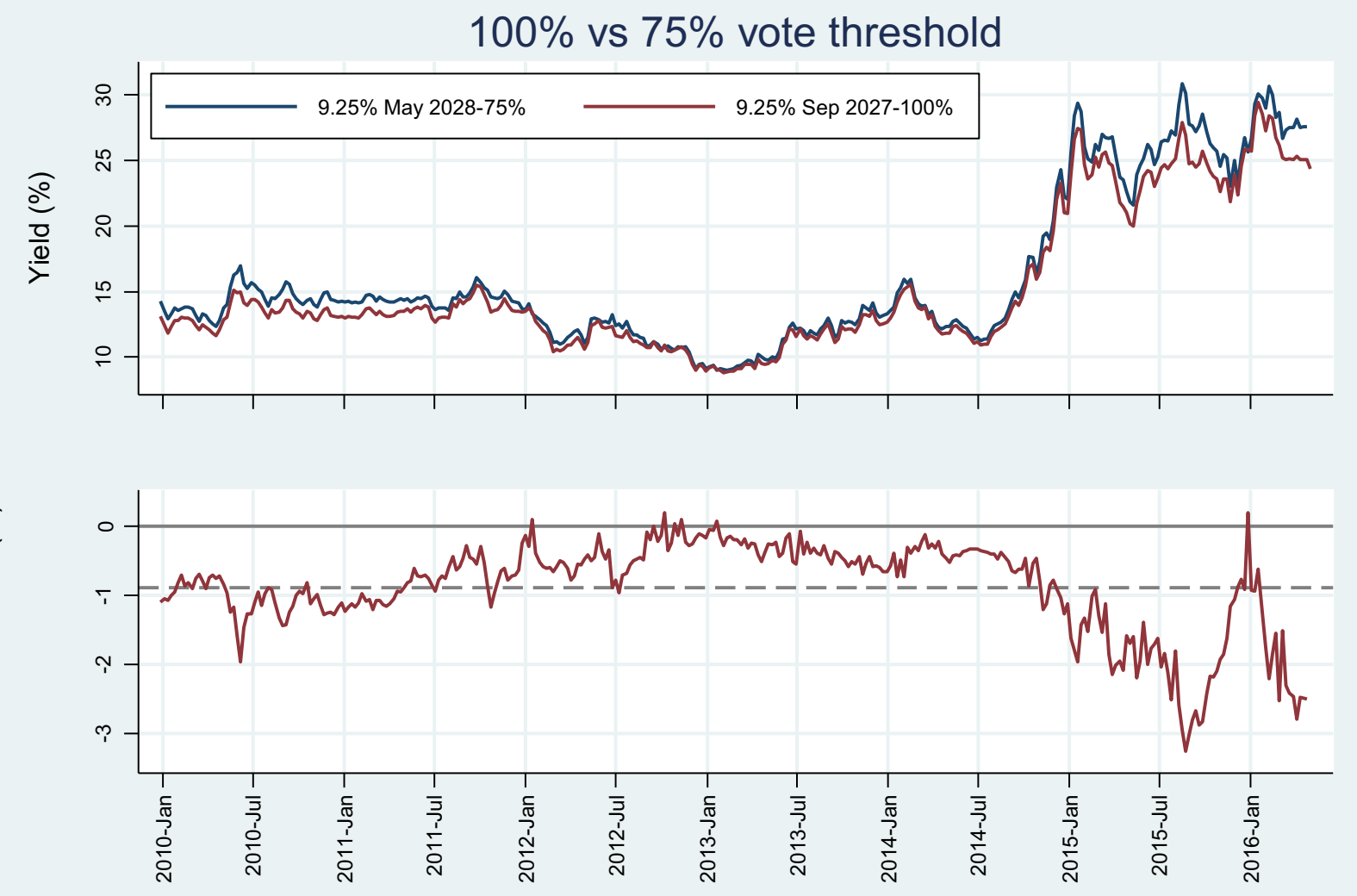


Figure $2.85 \%$ vs $\mathbf{7 5 \%}$ vote threshold. Weekly time series of average yields for the $7 \%$ December 2018 (ISIN USP97475AD26) and the 7.75\% October 2019 (ISIN USP97475AN08) bonds (top panel) and yield differential between the two bonds (bottom panel). The dashed line in the bottom panel indicates the average yield differential (19 bps).

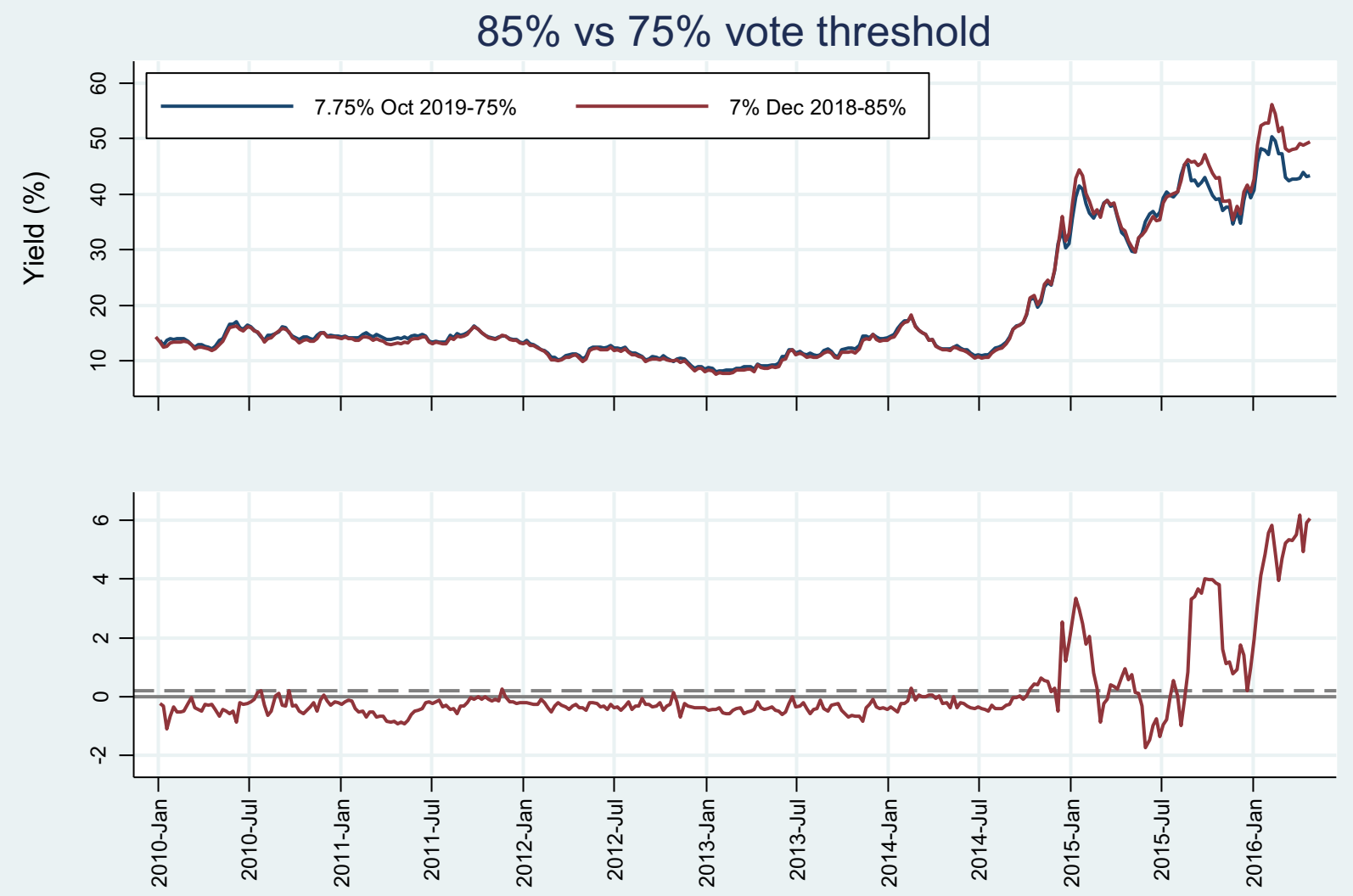


Figure 3. Venezuela credit quality. Weekly time series of average rating across Fitch, Moody's and Standard \& Poor's (Rating, left axis) and 5YR CDS spreads (log \%, right axis).

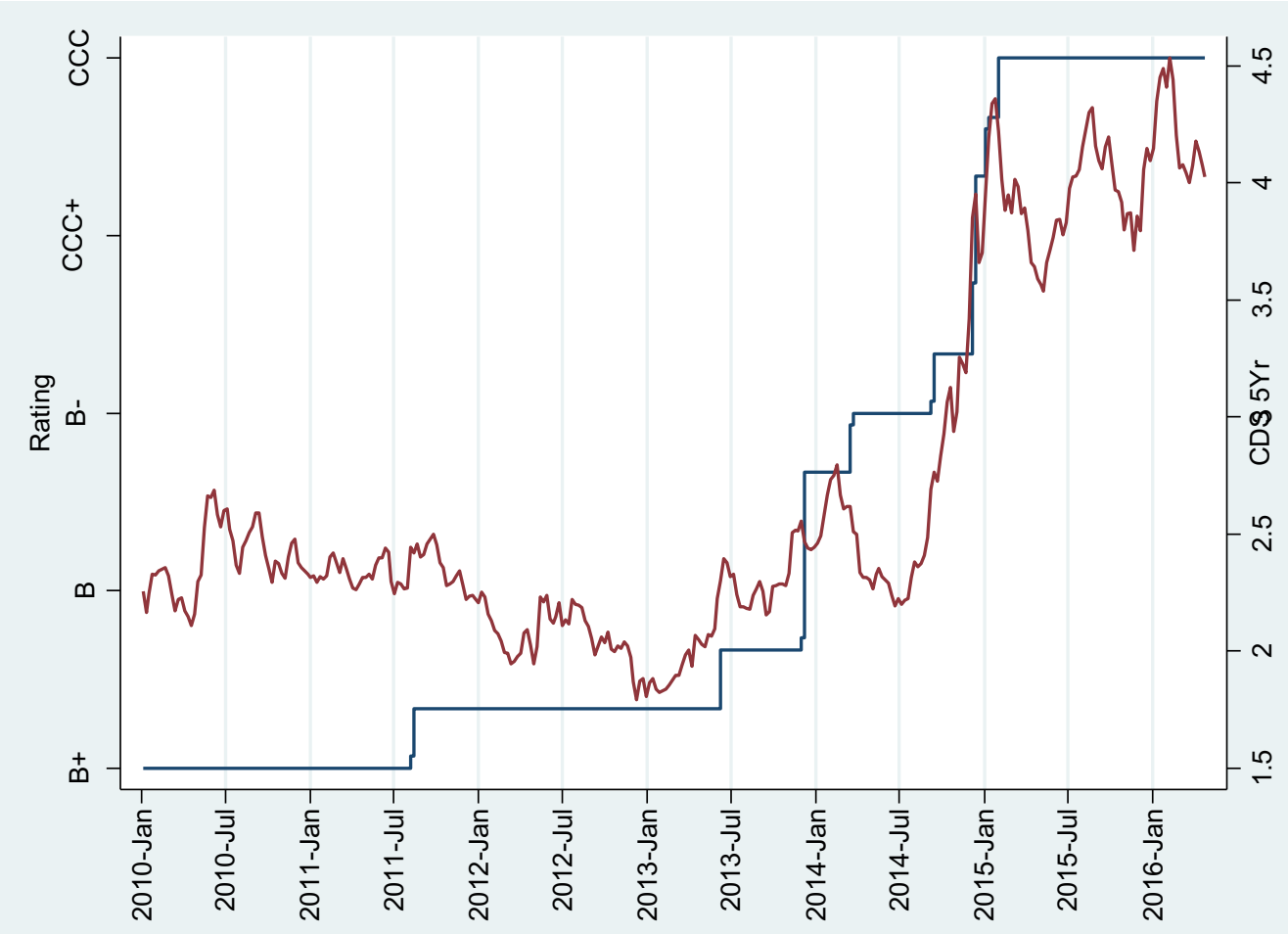

